\title{
Review: Book Review
}

Reviewed Work(s): A Literary Tour de France: The World of Books on the Eve of the French Revolution by Robert

Review by: Malcolm Walsby

Source: Libraries: Culture, History, and Society, Vol. 4, No. 1 (2020), pp. 113-115

Published by: Penn State University Press

Stable URL: https://www.jstor.org/stable/10.5325/libraries.4.1.0113

JSTOR is a not-for-profit service that helps scholars, researchers, and students discover, use, and build upon a wide range of content in a trusted digital archive. We use information technology and tools to increase productivity and facilitate new forms of scholarship. For more information about JSTOR, please contact support@jstor.org.

Your use of the JSTOR archive indicates your acceptance of the Terms \& Conditions of Use, available at https://about.jstor.org/terms 


\title{
Darnton, Robert. A Literary Tour de France: The World of Books on the Eve of the French Revolution. New York: Oxford University Press, 2018. ISBN: 9780195144512 . Hardcover: \$34.95.
}

\author{
Reviewed by Malcolm Walsby, École Nationale Supérieure des Sciences de \\ I'Information et des Bibliothèques, Lyon \\ doi: 10.5325/libraries.4.1.0113
}

Robert Darnton has spent decades studying and writing about one of the main purveyors of books for the French market in the late eighteenth century: the Société typographique de Neuchâtel or STN. The archives of the company have, extraordinarily, survived and offer a unique perspective on the books published in Switzerland and exported to France. Throughout his distinguished career as an historian of the enlightenment book, Darnton has used this source in order to build an alternative vision of the French book world that otherwise has often relied on Paris-centric documentation preserved in the great libraries and archives of the capital. This is therefore a work that analyzes the book in provincial France where 97 percent of the kingdom's population lived. It gathers together all the research he has previously undertaken and presents it in a more accessible and wider audience format, hopefully bringing his work to the attention of readers who have not previously read his articles and monographs. Simultaneously translated into French, this is, then, an important summation of Darnton's research.

This is presented through the lens of what he terms a literary Tour de France, perhaps just as much as an echo accounts such as Arthur Young's celebrated Travels in France, cited in the first chapter, as a reference to the annual multistage cycling race. The Tour he describes stems from a genuine journey undertaken by a contemporary figure. In 1778 a representative of the STN traveled the length and breadth of France in order to visit the local retail booksellers who sold the Sociétés wares - a standard practice for publishers. The particular interest of this source is the description of the system of distribution, the checking and organizing the delivery of volumes. This was vital to the STN: the Swiss company rose to fame and fortune because it offered texts that were censored in France, which meant that the network relied on illicitly importing bales of books into the kingdom and transporting them to the various outlets without being intercepted by the authorities.

The smuggling of these Neuchâtel imprints, Darnton argues, helps us better understand what the world of books really resembled on the eve of the Revolution. To emphasize his points, each chapter couples the description of a 
stop (or on some occasions of a series of stops) with the issues that he identifies as crucial to our understanding of this world. Often the examples used in each chapter include material gathered from the letters sent from other cities in order to strengthen the arguments he makes.

The study starts in Neuchâtel where our hero, Jean-François Favarger, prepared his departure, having his coat repaired, and buying essentials such as a couple of pistols. Darnton's description of the representative conveys the image of a business-like character intent on appearing decent and being taken seriously, more trusting of merchants who shared his Protestant faith. The first stop was just over the border in Pontarlier where the reports sent back open up the issue of book smuggling and the issues surrounding getting forbidden books safely past the French border and the multiple actors involved. They also emphasize the fierce competition between rival publishers, with the STN having no qualms about denouncing a competitor to the French authorities.

The following chapters concentrate on the towns along the Rhône and highlight the interaction between the representative and the shops he visited. They describe how Favarger evaluated the people, their businesses, and their wealth, and how the distribution of the books - and payments for them-was organised. Here, confidence emerges as a vital part of how they are assessed. Central to this section is Lyon, historically an important centre for print that featured 'some of the toughest customers in the publishing industry' (p. 67), but was also a hub for unauthorised reprints. Discussions with local traders were difficult and demanded considerable time and effort to ensure that publication projects and the dissemination of imported bales operated smoothly.

The towns of southern France visited by Favarger were far less promising ground for the STN. Bookshops seemed few and far between and mainly concentrated in the large cities. Even in some of these, such as Marseille, Bordeaux, or Toulouse, the sale of books was surprisingly sluggish. Darnton uses the two chapters devoted to them to demonstrate the varying nature of the booksellers with whom the STN traded, their conflicting strategies and fortunes, and how the company dealt with unpaid debt. Overall the south of France was disappointing.

Further north, Loudun offers the opportunity to delve into the shadowy world of peddling and of alternative manners of book distribution, what Darnton calls the "capillary system of the book trade" (183). This refers to the distribution of books from a modest center using a network that distributed 
books in small quantities via book peddlers. The contrast with the other, more established booksellers, is also the theme of the following stops made by Favarger as he turned back eastward, though his success was limited, even in Dijon, a city known for its taste for books. The final stop in Besançon highlighted the importance of the twin issues of communication and transportation in creating a successful connection with retailers. It certainly seems noteworthy that the STN enjoyed its best relations with booksellers situated in the towns broadly situated in eastern France.

Following this city-by-city overview, Darnton devotes the rest of his book to the question of which books were being sold or, more specifically, what literature was being sold in France. He underlines the fact that official registers are of little use here because of the enormous quantities of works that were either produced illicitly or imported from abroad by companies such as the STN. Darnton refutes the "fatally flawed" methodology used by other projects, such as The French Book Trade in Enlightenment Europe, $1769-1794$ (274) that attempt to enumerate every sale recorded by the STN. This ignores what he terms the "hit-and-miss" nature of extant archival information. Instead, he opts for sampling combining qualitative and quantitative approaches. He cautiously lists caveats before presenting a list of bestsellers from which he extrapolates the main themes: scandalous libels, enlightenment books, general fiction, travel literature, but also more serious works. He also notes a surprising number of children's books as well as various political editions and some titles linked to freemasonry and magic.

Darnton's study of the circulation of books in pre-revolutionary France benefits from his wealth of experience, though limited in truth to the fabulous archive of the STN. He is struck by what he terms the "lust for money" (xiii), which dominates the study, though he admits this might in part be due to the type of records that survive. It does serve to emphasize the central role of booksellers - and not just that of the publishers or readers-and underlines the diversity of the profession. Thanks to its strong narrative, the book provides the most engaging and clearest overview yet of how literature was distributed in late eighteenth-century France. Of all the books featured, the Encyclopédie is most regularly analyzed, though Darnton notes that by feeding the public with this and other Enlightenment works, booksellers had no inkling that they were aiding the cause of a future revolution that would lead to the collapse of the system on which they depended. Ultimately, it was, he concludes, a world of lost illusions. 